\title{
SPORTAKTIVITÁS ÉS ÉTREND-KIEGÉSZÍTŐK FOGYASZTÁSÁNAK ÖSSZEFÜGGÉSEI
}



SPORTS ACTIVITY VS. CONSUMPTION OF DIETARY SUPPLEMENTS

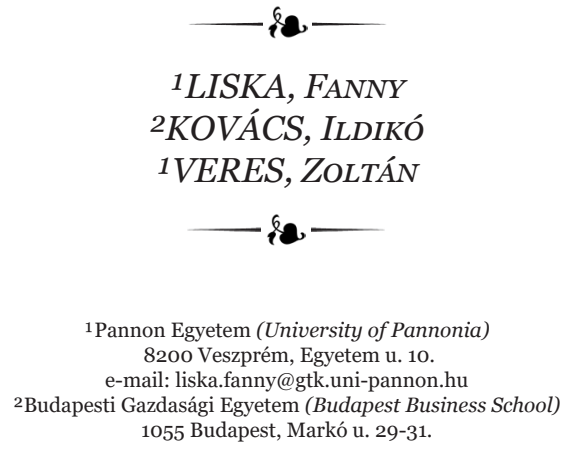

gi

Previous research on consumption of dietary supplements and consumer motivations has shown that there are different motivations behind their widespread consumption in recreational and competitive sports. This research examined the consumption of the main nutritional supplements, the relationship between different forms of sports and dietary supplement consumption, as well as their relationship with age. The questionnaire survey was conducted by telephone among those who mainly exercised recreational sports activities and a total of 236 valid responses were obtained. The sample is gender-balanced and overrepresents younger segments by age groups. The majority of recreational athletes interviewed in the research are among the potentially stable consumers. Only $10 \%$ does not consume and does not plan to use supplements. The interview recorded the main types of supplements (vitamins and minerals; amino acids, proteins; essential fats, etc.) as well as the preferred forms of sports (device-free and device-intensive aerobics and cardio; fitness and team sports). As for the purpose of consuming dietary supplements it can be said that the main motivator is the preservation of health, followed by the improvement of physical well-being, cartilage protection, muscle gain, and then performance enhancement. Among other things, the research revealed differences in consumption motivations for dietary supplements by age group, the relationship between sports type and dietary supplement consumption. Health preservation as motivation spans different age categories, however, cartilage protection and improvement of physical well-being are more typical for the $25^{+}$and $35^{+}$age groups, while supplements consumed to increase muscle mass and performance shift to the younger side of the sample. Different patterns appear for each type of sport, only the outstanding rate of consumption of vitamin preparations is the same. Device-free aerobic and cardio 91\%, deviceintensive aerobic and cardio $88 \%$ and fitness sports $85 \%$ are the proportions of people who often consume vitamin preparations several times a day, once a day or several times a week. The results suggest that the primary driver of the use of dietary supplements is the preservation of health, but product knowledge is an important consideration, as excessive intake of these supplements can even lead to damage to health.

KuLCSSZAVAK: szabadidős sportaktivitás, étrend-kiegészítő fogyasztás, fogyasztási motivációk
KEYWORDS: recreational sports activity, dietary supplement consumption, consumer motivations

JEL-KóDOK (JEL CODES): I12, M31, Z2

DOI: https://doi.org/10.20494/TM/8/2/3 


\section{BEVEZETÉS - INTRODUCTION}

Manapság számtalan marketingkommunikációs csatornán folyamatosan áramlik az üzenet a táplálkozási termékek kínálatáról, ezen belül az étrend-kiegészítőkről. Nem túlzás azt álítani, hogy a kívánatos testképpel együtt ezen termékkategória dominanciája - mintegy a téma hype-olása - a reklámpiacon szignifikáns, és az üzenetet a gondosan felépített hibrid disztribúció is támogatja. Az elérni kívánt testkép felértékeli a testmozgás, majd az ebből kifejlődő változatos sportaktivitás szerepét a mindennapi életben. Az érintett iparág(ak) számára természetesen az egészséges életmóddal való fogyasztói azonosulás a profitabilitás kulcstényezője. A nem-professzionális célcsoportok preferenciáinak megismerése, a felelős táplálékfogyasztás motivációinak megértése lényeges elem a hatékony marketingkommunikáció kidolgozásához. A professzionális testedzés pótlása szabadidős sportaktivitás formájában jelenik meg mára egyre több korcsoportban. Joggal feltételezhető egyfajta társadalmi - közelebbről életkori - átrendeződés, abból kiindulva, hogy a múlt század utolsó évtizedeire jellemző „fitnessőrület” helyét napjainkra átvette egy társadalmi elváráson alapuló életmód-kombináció: a sportaktivitás és az egészséges táplálkozás együttese. 2014-ben az EU-ban a férfiak 36\%-a, míg a nők 26\%-a töltött hetente 150 perc vagy annál is több időt sportolással, összesen pedig a 15 év feletti lakosság 43\%-a sportol rendszeresen, hetente legalább egyszer. Magyarországon ez az arány 33,5\%-ot mutatott, ami jelentős lemaradás az EU átlaghoz képest (EUROSTAT, 2014). A Pécsi Tudományegyetem felmérése szerint a 2020. évi $36 \%$ os arányról a COVID 19 járvány hatására $22 \%$-ra esett vissza azok aránya, akik rendszeresen sportolnak szabadidejükben (ÁCS, 2020). A szabadidős sportolás motivációi között kimagaslóan az egészség megőrzése, valamint a testi és lelki kikapcsolódás jelenik meg (KINCZEL et al., 2020), amely az egészségtudatos magatartás erősödésével egyre népszerúbbé válik (SZABÓ et al., 2020). Ugyan így az étrend-kiegészítók fogyasztása is megélénkült az elmúlt évtizedekben, azok vélt vagy valós pozitív egészségügyi- vagy testérzeti hatása miatt. Jellemző ugyanakkor, hogy a fogyasztók a szakemberek tanácsadása helyett a saját többnyire internetes - kutatásuk alapján döntenek arról, hogy mi kerül a kosarukba (MEER et al., 2005).

Ezek alapján célszerünek látszik az egészséges életmód, a sportaktivitás és a táplálékkiegészítők fogyasztásának vizsgálata, az étrend-kiegészítő fogyasztás motivációinak megismerése. Kutatásunk során a fóbb táplálékkiegészítők fogyasztását, a különböző sportolási formák és tétrend-kiegészítő fogyasztás összefüggéseit, valamint ezek életkorral való kapcsolatát vizsgáltuk.

\section{1. Étrend-kiegészítők fogyasztása, motivációk - Consumption of Food Supplements, Motivations}

Az étrend-kiegészítők rendszeres használata egyre inkább megjelenik már az egyre fiatalabb korcsoportok esetében is a legtöbb fejlett gazdaságú országban. Az étrend-kiegészítók a hazánkban is érvényben levő európai uniós szabályozás szerint „olyan élelmiszerek, amelyek a hagyományos étrend kiegészítését szolgálják, és koncentrált formában tartalmaznak tápanyagokat vagy egyéb táplálkozási vagy élettani hatással rendelkező anyagokat, egyenként vagy kombináltan." Az étrend-kiegészítőkről szóló 37/2004. (IV.26.) ESZCSM rendelet alapján tápanyagok alatt vitaminok, vagy ásványi anyagok értendók (OGYÉI, 2019).

Egy a Fortune Business Insights által 2020ban készített jelentés megállapította, hogy az étrend-kiegészítók globális piaca már 2019ben 108 milliárd amerikai dollár volt, és az előrejelzések szerint 2027-re eléri a 185,16 milliárd dollárt, mintegy 6,4 százalékos növekedést prognosztizál a 2020-2027 közti periódusra. Az európai piacon az értékesítés értéke 2020ban megközelítőleg 7,9 milliárd eurót tett ki, és az Euromonitor International adatai szerint az étrend-kiegészítók európai piacának évi mintegy 9,5\%-os növekedése várható. Ami a hazai helyzetet illeti, Dr. Horányi Tamás, a Magyarországi Étrend-kiegészítő Gyártók és Forgalmazók Egyesülete (MÉKISZ) alelnöke szerint ez a piac folyamatosan növekszik, és 2019-ben már 40 milliárd forintos nagyságrendú volt (TISZA, 2019). A Tárki 2019-es kutatása szerint a 18-22 évesek 46,7 százaléka, a 23-30 
évesek 60 százaléka, míg a 31 évesnél idősebb korcsoport 65,4 százaléka szedett már életében legalább egyszer étrend-kiegészítőt, vagyis a 30 év felettiek az ilyen jellegü készítmények elsődleges fogyasztói (STORE INSIDER, 2020).

Az étrend-kiegészítők fogyasztását és a fogyasztói motivációkat vizsgáló korábbi kutatások rávilágítottak arra, hogy a szabadidős és versenysportok esetében is elterjedt fogyasztásuk mögött különböző motivációk húzódnak meg. Egy flamand kutatás arra az eredményre jutott, hogy már kisgyermekkorban is jellemző lehet az étrend-kiegészítők fogyasztása. HUYBRECHTS és szerzőtársai (2010) kutatásában közel hétszáz fős mintán, szülői adatszolgáltatásból derült ki, hogy a gyermekek több, mint 30\%-a fogyaszt valamilyen étrendkiegészítőt. Jellemzően vitaminokkal és ásványi anyagokkal egészítik ki a mindennapi tápanyagbevitelt. Érdekes eredmény ugyanakkor, hogy az élelmiszerek által bevitt tápanyagok a D-vitamin kivételével mind meghaladják a mikro-tápanyagok ajánlott napi minimum beviteli értékét, tehát a táplálékkiegészítők szedése túlzott mértékű bevitelhez vezethet. Vélhetően az óvodás- és kisiskolás korban szülői hatásra berögzült táplálékkiegészítő fogyasztási szokások erősítik a felnőttkorban történő fogyasztás valószínűségét, akár sportmotivációs kapcsolódások nélkül, pusztán a vitalitás megőrzése céljából. PAJOR és szerzőtársai (2017) a társadalmi-kognitív és pszichoszociális tényezőket vizsgálták az étrendkiegészítőt fogyasztók és nem fogyasztók körében. A longitudinális vizsgálat arra engedte következtetni a szerzőket, hogy az egyének az alábbi motivációk mentén fogyasztanak étrendkiegészítő készítményeket:

- promóciókra való fogékonyság (esetenként impulzusvásárlás),

- környezetükben látnak étrendkiegészítő fogyasztásra példát,

- magasabbra becsülik a megbetegedési esélyeiket,

- pozitív hozzáállás az étrendkiegészítőkhöz. Ezzel szemben a nem-használók úgy vélik, hogy egyéb külső tényezők befolyásolják az egészségüket, és negatívan állnak hozzá az étrendkiegészítőkhöz. FROILAND és szerzőtársai (2004) atléták körében végzett vizsgálatukban az étrend-kiegészítő fogyasztás gyakoriságára fókuszáltak. A megkérdezettek 89\%-a étrend-kiegészítő fogyasztó, a leggyakoribb kategóriák az energiaitalok (73\%), kalóriapótló készítmények (61\%), multivitaminok (47\%), kreatin (37\%) és C-vitamin (32\%) voltak. A kutatás szerint az atléták jellemzően nem tekintik étrend-kiegészítőknek a sportitalokat és a kalóriapótló szereket. Testépítők körében végzett vizsgálatok (CHAPPELL et al., 2019) rámutatnak arra, hogy ebben a sportágban az étrend-kiegészítők széles körét alkalmazzák: protein por, BCAA (elágazó láncú aminosavak), C-vitamin, omega 3 zsírsavak, multivitaminok, kreatin, D vitamin, pre-workout étrendkiegészítők, szénhidrát komplexek, aminosavak, zsírégetők, ásványi anyagok, kombinált étrendkiegészítők (joint supplements), proteinszeletek és egyéb étrend-kiegészítők. Amerikában amatőr testépítők körében végeztek felmérést az étrend-kiegészítók fogyasztásával kapcsolatos percepcióikról (KING, 2014). A kiegészító készítmények fogyasztásával kapcsolatban 3 fó okot tárt fel a kutatás. Az amatőr testépítők étrend-kiegészítőt az alábbi okok miatt fogyasztanak:

1. ideális testalkat elérése,

2. erőnlét/izomerő növelése és teljesítményfokozás,

3. a fogyasztás előnyei meghaladják a lehetséges negatív következményeket.

A vizsgálat kimutatta, hogy az a testkép, amit a sportág és a nyugati fitneszkultúra reprezentál, egyaránt kiválthat pozitív és negatív viselkedést a kiegészítő készítmények fogyasztása kapcsán. Az amatőr testépítők szükségét érzik az étrend-kiegészítők fogyasztásának, hogy elérjék az áhított testképet, vagy hogy sikeresen teljesítsenek versenykörnyezetben.

Bizonyos nemi polarizálódás megfigyelhető a bevitel motivációiban: míg a női válaszadók egészségmegőrzési célból vagy egy diéta kapcsán fogyasztanak étrend-kiegészítőket, kiemelten a zsírvesztés céljából (HOUSMAN, 2003), addig a férfiaknál a sebesség, robbanékonyság fokozására és a súly és/vagy izomtömeg gyarapítására fókuszálnak. A nők inkább családtagoktól, ismerősöktől tájékozódnak az étrend-kiegészítőkkel kapcsolatos kérdésekben, a férfi válaszadók a táplálkozási szakértőket, az üzletekben megkérdezhető szakértőket, sporttársakat, barátokat vagy coach-ot preferálják (FROILAND et al., 2004). A férfiakra 
gyakorolt szociokulturális nyomás hatására sok férfi igyekszik hipermaszkulinitással megerősíteni társadalmi és nemi identitását (MASON, 1992). Ennek következtében például a férfi testépítők jellemzően magas gyakorisággal használnak étrend-kiegészítőket és különböző tömegnövelő szereket (HACKETT et al., 2012). Megfigyelhető az is, hogy az étrend-kiegészítők közül a fehérjekészítmények fogyasztása emelkedik a szabadidősportolók körében (HARTMANN és SIEGRIST, 2016). Svájci felnőttek körében végzett kutatások szerint a megkérdezett nők fehérjekiegészítők fogyasztásának fő driverei az izomtömeg-növelés (57,3\%) és a testsúly-kontroll (48,6\%) voltak, míg férfi válaszadók esetében az izomtömeg növelése toronymagasan $(83,7 \%)$ vezetett a regeneráció elősegítése (53,7\%) mellett. Mindemellett azonosítható négy különböző hasznossági percepció is, amelyet a fogyasztók az étrend-kiegészítő készítmények fogyasztásához társítanak, mégpedig (1) a tápanyagfogyasztás egyensúlya, (2) a fittség, mint trend, (3) egészség és jólét, valamint az (d) izommoduláció és versenyképes teljesítmény.

\section{2. Étrend-kiegészítő fogyasztás és a sportteljesítmény kapcsolata - The Relationship Between Dietary Supplement Consumption and Sport Performance}

Nem csak motivációnként térnek el az étrend-kiegészítők fogyasztásának szokásai, hanem sportolási intenzitásonként is. Egy többezres mintán végzett német kutatás szerint azok a férfiak és nők, akik aktívan sportolnak, a napi tápanyagbevitelük 3\%-át fedezik étrend-kiegészítőkből (BEITZ et al., 2003). A megfelelő táplálkozás természetesen jelentősen befolyásolhatja a sportteljesítményt. A fizikai aktivitásnak ugyanakkor számos előnye van, beleértve a zsírmentes testtömeg (lean body mess) növekedését és a nyugalmi anyagcserefolyamatok sebességének növekedését, amelyek pozitívan hatnak az étvágyra.

$\mathrm{Az}$ értékesítési mutatók azt mutatják, hogy a sportkiegészítők fogyasztása tovább növekszik a fiatal sportolók körében, a kutatások szerint pedig a fiatal sportolók lettek a marketing fó célpontjai (HOUSMAN, 2003).
Ezenkívül a nagyobb sportteljesítmény vagy az ideális testkép elérésére irányuló nyomás erős motiváció a fiatal sportolók számára. KISS és szerzőtársai (2020) a szabadidős sporttevékenységet végzők körében azt találták, hogy az étrend-kiegészítők fogyasztása közvetlen kapcsolatban van a sporttevékenység intenzitásával és fogyasztásuk vélelmezett fontosságával, de közvetve a kockázatviselési attitűd és mások véleménye is befolyásoló tényező. Az étrend-kiegészítők fogyasztásának különbségeit tekintve SÁNCHEZ-OLIVER és szerzőtársai (2021) eredményei alapján elmondható, hogy a megkérdezettek jellemzően a sportteljesítmény fokozása érdekében fogyasztanak különféle készítményeket (protein, koffein, sportitalok, energiaszeletek, kreatin monohidrátok), mindemellett a versenyszerüen sportolók jellemzően a felkészülési időben és versenyidőszakban is rendszeres használók, az amatőr sportolók inkább versenyekhez kapcsolódóan fogyasztják intenzívebben a kiegészítő készítményeket. A válaszokból az is kiderült, hogy a versenyszerűen sportolók többnyire az edzés utáni kiegészítőkre is fókuszálnak, míg az amatőr réteg az edzés előtti bevitelre fordít nagy figyelmet. Jelen vizsgálatnak nem tárgya, de természetesen valamely táplálkozási szegmenshez tartozás (pl. vegán) szignifikáns sajátosságokat mutat az étrend-kiegészítők bevitelében is (WIRNITZER et al., 2021).

LOCQUET és szerzőtársai (2016) amatőr női futók körében végzett kutatása szerint az amatőr futónők 34,6\%-a számolt be arról az anonim megkérdezés során, hogy a futóverseny előtt önállóan összeállított tabletta és étrend-kiegészítő "csomagot” fogyasztott el, a futóteljesítményének fokozása céljából. A kutatás rámutat arra is, hogy a különböző gyógyszerek és étrend-kiegészítő készítmények fogyasztása arányosan növekszik a spottevékenység intenzitásának növekedésével. CÖNDÜ és szerzőtársai (2019) kutatása rámutat arra, hogy csapatsportok esetében a versenysportban résztvevők táplálkozásában szignifikánsan nagyobb arányban jelennek meg étrend-kiegészítő készítmények. Amatőr teniszezők jellemző étrend-kiegészítő fogyasztása egy 2018-as tanulmány szerint a sportitalokból, energiaszeletekből, vitamin-komplexekből, proteinekből és kreatinból tevődik össze. A megkérdezettek 
arról számoltak be, hogy az étrend-kiegészítő készítmények fogyasztásával pozitív hatást érzékelnek fizikai erőnlétük és sportteljesítményük vonatkozásában (SÁNCHEZ-OLIVER et al., 2018). Ez egyfajta motivációként szolgál a fogyasztóknak, hiszen az étrend-kiegészítők használata a sportteljesítmény javulásának eredményével kecsegtet.

Az önállóan, szakmai kontroll nélkül fogyasztott étrend-kiegészítők és különféle tabletták azonban nem feltétlenül váltanak ki jótékony hatást. Számos étrend-kiegészítő tartalmazhat olyan anyagokat, amelyeket a versenysportban tiltanak, mindemellett jelentős egészségügyi veszélyekkel is járhatnak hosszútávú fogyasztás esetén. Az ilyen kiegészítő termékeket fogyasztó sportolók veszélyeztethetik fizikai állapotukat, állóképességüket és egészségüket (PIPE és AYOTTE, 2002).

\subsection{A fogyasztók termékismerete - Product Knowledge of Consumers}

Az edzőtermek és fitnesz-klubok előszeretettel népszerűsítik az aktív életmódot, mint az egészségmegőrzés egyik fő komponensét. Napjaink testkultuszában már nem pusztán a fizikai aktivitási célokért küzdenek az edzőtermekben, hanem növekvő hangsúlyt kap a szálkás fizikum és az arányosság is (KARPIK et al., 2020). Tájékozatlan felhasználók esetében számos táplálkozási hiba és helytelen étrend-kiegészítő fogyasztás figyelhető meg. Az egyik legsúlyosabb hiba a helytelen (jellemzően túlzott) fehérjebevitel, amely kontraverzív hatású lehet: olyan negatív egészségügyi hatásai lehetnek, mint a veseelégtelenség, dehidratáció, súlygyarapodás, emésztési problémák és depressziós hajlam. A túlzott proteinfogyasztás a fiatal és egészséges szervezetre is káros hatással van. Tudományos megfigyelések támasztják alá, hogy a gyermekeknél alkalmazott magas fehérje tartalmú étrend negatív hatással lehet csontvázuk fejlődésére, sőt anyagcsere-betegségekhez és vesekárosodáshoz vezethet (BONJOUR, 2016; FENTON et al., 2020; LENTINE és WRONE, 2004; LINN et al., 2000; MANGANO et al., 2015). LEHOTA és szerzőtársai (2015) a hazai lakosság mintáján vizsgálták az étrend-kiegészítők termékinformációi, a fogyasztók termékismerete és a fogyasztás kockázatainak összefüggéseit. Elemzésük egyik konklúziója, hogy a szegmentált piac differenciált marketingmunkát igényel.

Részben hasonló célú kutatást közöl MARKOS és KISS (2019) cikke, melyben amatőr férfisportolók kismintás interjúeredményeit mutatják be. A vonatkozó kutatási modul az étrend-kiegészítők tudatos fogyasztását igazolja. Ennek ellentmond KARPIK és szerzőtársai (2020) cikke, mely szerint az amatőr testépítők tudása hiányos az étrend-kiegészítők terén. SPARKS és szerzőtársai (2018) amatőr kerékpárosok körében végzett kutatása is rámutat arra, hogy a vizsgálatban résztvevőknek nem volt elegendő ismerete az étrend-kiegészítők összetevőiről és felhasználásáról. SWISTOB (2018) tanulmánya ugyancsak rámutat arra, hogy sok amatőr sportoló hiteltelen vagy nem szabályozott forrásból szerez információt, ezért a fehérjefogyasztással kapcsolatos elképzeléseik tévesek lehetnek. Az amatőr sportolók körében a fehérjekiegészítők használatának gyakorisága egyre inkább elfogadott életmód-gyakorlattá válik. Számos amatőr felhasználó gondolja úgy, hogy a fehérjekiegészítők elengedhetetlenek sportcéljaik eléréséhez. Ezek a téves percepciók és átmeneti észlelt előnyök helytelen étkezési szokásokhoz vezetnek.

Végül meg kell jegyezni, hogy az utóbbi években Magyarországon is megjelent az étrend-kiegészítők hamisítása, mint egy újabb veszélyforrás, ezért - Bérci Istvánt, a MÉKISZ elnökét idézve - „Az étrend-kiegészítők iránti kereslet növekedése miatt különösen fontos a fogyasztók megfelelő tájékoztatása annak kapcsán, hogy honnan érdemes ezeket a szereket beszerezni." (STORE INSIDER, 2020).

\subsection{Kutatási kérdések - Research Questions}

A szabadidős sportolók körében végzett jelen kutatás egyik alapozó célja megismerni azoknak a fogyasztóknak a demográfiai és sportolási jellemzőit, akik a felmérésben jelenleg is aktív étrendkiegészítő fogyasztóknak vallották magukat. Az étrend-kiegészítők fogyasztásának motivációi és ezek eltérései az egyes sportkategóriákban szintén vizsgálódás tárgyát képezték. Ezen túl pedig az egyes sportkategóriák szerinti étrendkiegészítő fogyasztási gyakoriságot vizsgálja a kutatás. 


\section{ANYAg ÉS MÓDSZER - MATERIAL} AND METHOD

A kérdőíves lekérdezés telefonos formában valósult meg, összesen 236 értékelhető válasz született. A telefonos megkérdezés választását az indokolta, hogy ezzel lényegesen csökkenthető az önkitöltő kérdőívekre jellemző sematikus válaszadás. A lekérdezés 2021. Első negyedévében zajlott, a mintavétel előzetes szürésen alapult: olyan válaszadókkal futott le a megkérdezés, akik sportolási gyakorisága elérte a minimum havi 3 alkalmat. Ezen kívül a demográfiai összetételben ügyeltünk a kiegyenlített nemi viszonyokra, továbbá az életkori csoportok egyenletes eloszlására oly módon, hogy az első három korcsoportban egyenként 30\%, a legidősebb csoportból pedig nagyságrendileg 10\% legyen a minta béli arány.

A kérdőív demográfiai adatokkal indult, majd a sporttevékenység kereteire kérdezett rá (szabadidős vagy egyesülethez köthető (verseny) sport). A kérdőív kitér a sporttevékenység típusára, ahol több sportág is említhető volt. A továbbiakban a sportolási motivációkhoz kapcsolódó attitűdállítások kaptak helyet. Ezután a kérdőív az étrend-kiegészítők témakörére fókuszál, elsőként arra, hogy fogyaszt-e a válaszadó bármilyen készítményt, és amennyiben igen, úgy milyen típusúakat, milyen gyakorisággal és mi célból. Az előzetes kritériumoknak megfelelően nemek szerinti megoszlást tekintve körülbelül kiegyenlített (45\% férfi; 55\% nő) módon jelennek meg válaszadók. Korcsoportok szerint ugyanakkor a mintastruktúra szándékoltan aszimmetrikusan kvótázott, leszorítva a 45 éves kor feletti szegmens válaszadóinak számát. Így tehát az elemzett adatok korcsoportösszetétele a következők szerint alakult: 18-24 évesek 30\%, 25-34 évesek 30\%, 35-44 évesek 29\% és 45-54 évesek 11\%. A kérdőív kitöltésének feltétele volt, hogy minimum havonta 1-3 alkalommal végezzen sporttevékenységet a kitöltő, ennek megfelelően ez a gyakoriság jelentette a skála legalját. A válaszadók közel kétharmada hetente többször végez sporttevékenységet (142 fó, 60,2\%), a második leggyakoribb válasz a naponta $1 \mathrm{x}$ történő sporttevékenység volt (42 fő, 17,8\%). A mintát kevésbé jellemzik a szélsőségek: a napi rendszerességgel sportolók a válaszadók 6,4\%át teszik ki, hetente egyszer a válaszadók 8,5\%a, havonta 1-3 alkalommal 6,8\%-uk sportol.

A válaszadók $81 \%$-a szabadidős sportokat üz, így az eredmények a szabadidősportokhoz köthető étrend-kiegészítő fogyasztással és motivációkkal kapcsolatban szolgáltatnak mélyebb információkat. Sporttípusokat tekintve dominánsok az aerob jellegű sportok. Legnagyobb gyakorisággal a futást (42,5\%) említették a válaszadók, ugyanakkor megjelent az erónléti edzésformák közül a súlyzós edzés (kondicionálóteremben) és testépítés kategória (37,1\%). A harmadig legnagyobb gyakorisággal szereplő szabadidősport a fitnesz (34,9\%) volt, majd a kerékpározás (28,0\%), az aerobik (14,5\%) és a jóga (14,5\%) szerepel a toplistán. A szabadidősportolók körében a csapatsportok mérsékelten jellemzőek, ezek közül a labdarúgást említették a legtöbben (7,0\%), majd a kosárlabda $(4,3 \%)$, a röplabda $(3,2 \%)$ és a kézilabda $(1,6 \%)$ jelent meg a válaszokban.

$\mathrm{Az}$ adatok elemzését SPSS Statistics 27 programmal, leíró statisztikai módszerekkel végeztük, leíró statisztikai mutatókat és kereszttábla-elemzést alkalmaztunk. A szegmensek közötti eltérések vizsgálata során asszociációs összefüggés-vizsgálatokat végeztünk.

\section{EREDMÉNYEK - RESUlts}

\subsection{Az aktív étrendkiegészítő fogyasztók demográfiai és sportolási jellemzői - Demographic and Sport Characteristics of Active Food Supplement Consumers}

A mintán belül az aktív étrend-kiegészítő fogyasztók aránya $83 \%$. A válaszadók 11\%-a jelenleg nem fogyaszt étrend-kiegészítót, de a jövőben tervezi, és mindössze 6\%-uk nem is fogyaszt és nem is tervezi a fogyasztást. Az étrendkiegészítők fogyasztására fókuszálva az alábbi eloszlás jellemzi a mintát (1. ábra): 


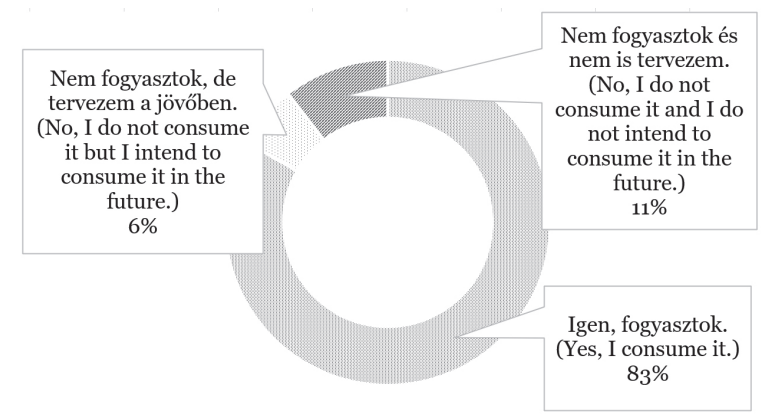

FIG. 1

Az étrend-kiegészítókfogyasztásának megoszlása a mintán belül (Distribution of Dietary Supplement Consumption Within the Sample)

Forrás (Source): Saját szerkesztés (Authors'own compilation)

Megjegyzés (Notes): $\mathrm{N}=236$

A szabadidős sportokat végző és emellett étrendkiegészítőket használó résztvevők (191 fő) szocio-demográfiai jellemzőiről elmondható, hogy a 43,5\% férfi és $56,5 \%$ női válaszadóval kissé átbillen a mérleg a női szabadidősportolók oldalára. Korcsoportonkénti bontásban a 18-24 éves korosztály 33\%, 25-34 évesek 25\%, 35-44 évesek 31\% és a 45-54 évesek 11\%-os arányban alkotják a csoportot. Sportolási gyakoriságot tekintve az étrend-kiegészítőt fogyasztóknál is a hetente többször végzett sporttevékenység $(66,5 \%)$ a legjellemzőbb, második leggyakoribb válasz a napi rendszerességü sport volt 13,1\%kal.

Érdekes eredmény, hogy azok a válaszadók, akik nem fogyasztanak étrendkiegészítőt, de tervezik a jövőben, 75\%-ban a fiatalabb, 18-24 év közötti férfiak közül kerültek ki, akik hetente többször sportolnak.

Az étrend-kiegészítők fogyasztásának kategóriáit vizsgálva az rajzolódik ki, hogy a vitaminok és ásványi anyagok pótlását oldják meg legtöbben (95\%) „külső” forrásból. Ezután az aminosavak és fehérjekészítmények a második leggyakrabban fogyasztott étrendkiegészítő (59,5\%), majd az esszenciális zsírok (40\%), végül egy egyéb testépítő kiegészítők következnek (37\%). A 2. ábra szemlélteti az egyes kategóriák fogyasztásának mértékét (N=191).

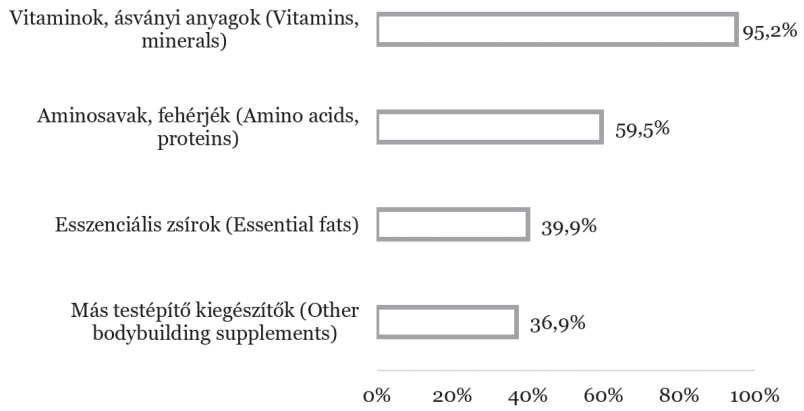

2. ÁBRA

Az étrend-kiegészítők fogyasztásának aránya az étrend-kiegészítőket fogyasztó szabadidős sportolók körében

(Proportion of Consumption of Food Supplements Among Recreational Athletes Consuming Food Supplements)

Forrás (Source): Saját szerkesztés (Authors'own compilation)

Megjegyzés (Notes): N=191 
Érdekes megfigyelni az étrendkiegészítő típusok fogyasztási gyakoriságának korcsoportonkénti eltéréseit. A kapott eredményekből az rajzolódik ki, hogy a vitaminok és ásványi anyagok fogyasztása minden korosztályra jellemző, a 35 év felettiek esetében pedig megjelentek a „naponta többször” történő fogyasztásra adott válaszok. Az aminosavak és fehérjék esetében nincsen korosztályi jellemző, míg az esszenciális zsírsavak fogyasztása inkább a 25 év felettiekre jellemző, és a kor előrehaladtával erősödik. Az egyéb testépítő kiegészítők napi egyszeri vagy heti többszöri fogyasztása a 2534 éves korosztályban a legjellemzőbb.
Az aktív étrend-kiegészítőt fogyasztók sportolási jellemzőit vizsgálva (3. ábra) legmagasabb arányban jelenik meg az aerob és kardio eszközmentes sportokban való részvétel (67\%). Az erőnléti sportok közel 20\%-os aránya mellett az aerob eszközigényes sportok jelennek meg (10\%) számottevő arányban. A csapatsportok kevésbé jellemzőek a vizsgált korcsoport szabadidős sportolási tevékenységében, különösen a 35-44 és 45-54 éves korban jelenik meg kevésbé, míg a 18-24, illetve a 25-34 éves korcsoportokban az aerob és kardio eszközmentes sportokkal párhuzamosan végzik.

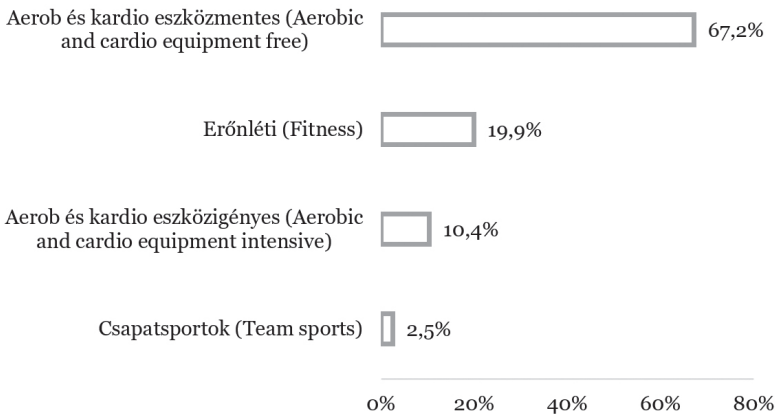

3. ÁBRA

Az aktív étrend-kiegészítőket fogyasztók sportolási jellemzői

FIG. 3

(Sport Characteristics of Active Supplement Consumers)

Forrás (Source): Saját szerkesztés (Authors'own compilation)

Megjegyzés (Notes): $\mathrm{N}=191$

Többségük, 63\%-uk hetente többször sportol, ennél gyakrabban, naponta 18\%-uk, naponta többször 7,5\%-uk. A ritkábban sportolók közül hetente a válaszadók 8\%-a, havonta 1-3 alkalommal pedig 4\%-a sportol. A ritkábban sportolók szignifikánsan gyakrabban $(\mathrm{p}<0,01$, Cramer's V=0,298) 37,5\%-uk aerob eszközigényes sporttevékenységet folytat, míg a magasabb gyakoriság mellett jellemzően az aerob eszközmentes sportok szerepeltek az említések között. A naponta vagy naponta többször sportolók körében magasabb az erőnléti sportokban való részvétel aránya (47\%), ami a többi sportolási gyakoriság esetében $12,5 \%$ és $17,5 \%$ között mozog ( $\mathrm{p}<0,01$, Cramer's V=0,298)

Összességében megállapítható, hogy a szabadidős sportokban résztvevő és aktív étrend-kiegészítőket fogyasztók esetében kiugró arányban jelennek meg a vitaminkészítmények. Sporttípus és sportolási gyakoriság tekintetében jelentős eltérés mutatható ki a mintán belül, illetve különösen a fiatalabb korcsoportban jelennek meg a különböző csapatsportok is az aerob eszközmentes sporttevékenység mellett a szabadidős sportok között.

\subsection{Az étrend-kiegészítők fogyasztásának motivációi - Motivations for Consuming Dietary Supplements}

Az étrend-kiegészítők fogyasztásának céljáról elmondható, hogy a fő motivátor az egészségmegőrzés, azt követi a fizikai közérzet javítása, a porcvédelem, az izomtömeg-növelés, majd a teljesítmény fokozása (4. ábra). 
4. ÁBRA



FIG. 4

Az étrend-kiegészítő fogyasztás motivációs tényezői az étrend-kiegészítőket aktívan fogyasztó szabadidős sportolók körében

(Motivational Factors of Dietary Supplement Consumption Among Recreational Athletes Actively Consuming Dietary Supplements)

Forrás (Source): Saját szerkesztés (Authors' own compilation)

Megjegyzés (Notes): $\mathrm{N}=191$

Lebontva az egyes sportkategóriákra az étrendkiegészítők fogyasztásának célját, az látható, hogy az egészségmegőrzés és a fizikai közérzet javítása minden csoportban dominál. Látható ugyanakkor, hogy az aerob/kardio jellegű, eszközhasználatot nem igénylő sportok esetében (pl. aszfalton történő futás) a porcok védelme domináns $(51,2 \%)$, míg az erőnléti edzésmódokat végzők esetében a porcvédelem mellett a teljesítmény fokozása $(42,1 \%)$ is hangsúlyos célként jelenik meg az étrend-kiegészítők fogyasztásával kapcsolatban. Az aerob eszközmentes sportok (pl. futás) esetében föként nők (62\%) jellemzően naponta (20\%) vagy hetente többször (68\%) sportolnak, életkorukat tekintve 18-24: 33\%, 25-34: 25\% 35-44: 31\% 45-54: $11 \%$. Az aerob eszközigényes sportok (pl. kerékpározás) esetében inkább férfiak (60\%) és jellemzően hetente többször sportolnak (45\%) hetente egyszer (20\%) naponta csak $5 \%$. Életkoruk szerint a mintán belül inkább idősebbek, 35\%-uk a 35-44 éves, 20\%-uk pedig a 45-54 éves korcsoportba tartozik. Az erőnléti sportolók mintán belüli megoszlását tekintve 92\%-a 44 év alatti és 80\%-ban hetente többször sportolnak, a nemek megoszlása nagyjából fele-fele arányban férfi (52\%) és nő (48\%).

Korcsoportonként vizsgálva az étrend-kiegészítők fogyasztásának célját az mondható el, hogy az egészségmegőrzés mint motiváció átível a különböző életkori kategóriákon, ugyanakkor a porcok védelme és a fizikai közérzet javítása inkább jellemző a 25+ és $35^{+}$ életkori csoportra, míg az izomtömeg növelése és a teljesítmény fokozása céljából fogyasztott étrendkiegészítők a minta fiatalabb oldalára tolódnak. Míg az izomtömeg növelése, mint motiváló erő sokkal inkább dominál a 18-34 év közöttieknél ( $\mathrm{p}<0,05$, Cramer's $\mathrm{V}=0,121$ ), a porcok védelme szignifikánsan magasabb arányban jelenik meg az idősebb, 25 év feletti korcsoportban ( $\mathrm{p}<0,001$, Cramer's V=0,341). A fizikai közérzet javítása esetében nincs számottevő különbség a korcsoportok között. 
1. TÁBLÁZAT

Az étrend-kiegészítők fogyasztási motivációinak korcsoportonkénti eltérései, \% (Differences in the Motivations for Consuming Food Supplements by Age Group, \%)

\begin{tabular}{cccccc}
\hline Korcsoport & $\begin{array}{c}\text { Egészség } \\
\text { megórzése } \\
\text { (Health }\end{array}$ & $\begin{array}{c}\text { Izomtömeg } \\
\text { növelése } \\
\text { (Increase } \\
\text { preservation) }\end{array}$ & $\begin{array}{c}\text { Porcok } \\
\text { védelme } \\
\text { (Cartilage } \\
\text { protection) }\end{array}$ & $\begin{array}{c}\text { Fizikai } \\
\text { Teljesítmény } \\
\text { fokozása } \\
\text { (Performance } \\
\text { enhancement) }\end{array}$ & $\begin{array}{c}\text { közérzet } \\
\text { javítása } \\
\text { (Improving } \\
\text { physical well- } \\
\text { being) }\end{array}$ \\
\hline $18-24$ & 88,7 & 43,4 & 34,0 & 37,7 & 37,7 \\
\hline $25-34$ & 95,7 & 42,0 & 60,9 & 49,3 & 47,8 \\
\hline $35-44$ & 96,7 & 31,1 & 50,8 & 29,5 & 59,0 \\
\hline $45-54$ & 86,4 & 31,8 & 68,2 & 22,7 & 45,5 \\
\hline
\end{tabular}

Forrás (Source): Saját szerkesztés (Authors'own compilation)

Megjegyzés (Notes): $\mathrm{N}=191$

\subsection{A sporttípus és étrend-kiegészítő fogyasztás összefüggései - Relationships Between Sport Type and Dietary Supplement Consumption}

Érdekes még rátekinteni az egyes sportkategóriákhoz kapcsolódó étrend-kiegészítő fogyasztási gyakoriságra. Ezzel kapcsolatban az mondható el, hogy a vitaminok fogyasztása az aerob/ kardio jellegú, valamint erőnléti mozgásformák esetében inkább jellemzően naponta többszöri, vagy napi egyszeri. Az aminosavak, fehérjék fogyasztásában az erőnléti kategória sportfogyasztói dominálnak, jellemzően napi többszöri, egyszeri vagy heti többszöri fogyasztással. Erre a sportolói csoportra az esszenciális zsírok fogyasztásának napi egyszeri bevitele is jellemző, emellett ezt az étrendkiegészítőt előszeretettel veszik magukhoz az eszközmentes aerob/kardio mozgást végzők. Megjegyzendő, hogy a zsírokkal kapcsolatban számos „soha” válasz érkezett, ez feltehetően két okból adódhat: egyrészt elképzelhető, hogy a szabadidősportokat végzők nincsenek tisztában az esszenciális zsírok fogyasztásának fontosságával, másrészt elképzelhető egy prekoncepció azzal kapcsolatban, hogy ,a zsír hizlal”, így tartanak a makrotápanyag direkt fogyasztásától. (Itt a közép-európai régióban azt a lehetőséget kizárhatjuk, hogy az elegendő halfogyasztáson keresztül bőségesen elegendő esszenciális zsí- rokhoz jut egy sportfogyasztó, ezért feleslegesnek tartja étrendkiegészítő formájában bevinni ezt a tápanyagforrást.)

Az egyéb testépítő kiegészítők fogyasztása az erônléti sportoknál (28\%) és az aerob/kardio mozgásformáknál (25\%) jelent meg napi vagy heti rendszerességgel.

Az 5. ábrán levő csoport étrend-kiegészítő fogyasztása szignifikáns különbséget mutat az egyes étrend-kiegészítők fogyasztása tekintetében ( $p<0,01$ Cramer's V=0,234), emellett pedig lényeges különbségként jelenik meg az aerob és kardio eszközmentes és az aerob kardio eszközigényes sportoknál megfigyelhető eltérés. Lényeges eredmény, hogy az aerob mozgásformák esetében kiemelkedően magas azok aránya, közel a válaszadók fele, akik soha nem fogyasztanak aminosavakat, fehérjéket, illetve esszenciális zsírokat (aerob eszközmentes 58\% és aerob eszközigényes 71\%)

Az étrend-kiegészítők fogyasztásában eltérő mintázatok jelennek meg az egyes sporttípusok esetében, egyedül a vitaminkészítmények fogyasztásának kimagasló aránya egyezik meg. Az aerob és kardio eszközmentes 91\%, aerob és kardio eszközigényes $88 \%$, az erőnléti sportok esetében pedig $85 \%$ azok aránya, akik gyakran: naponta többször, napi egyszer vagy hetente többször fogyasztanak vitaminkészítményeket (5. ábra). 


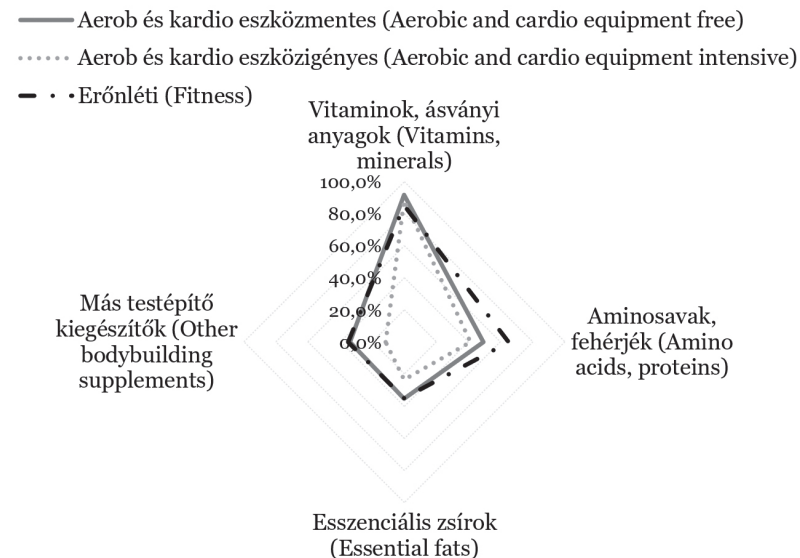

5. ÁBRA

(Essential fats)

\section{A naponta többszöri, napi egyszeri és a hetente többszöri fogyasztás aránya az egyes sportkategóriákban \\ (The Proportion of Consumption Per Day, Once a Day and Several Times a Week in Sport Categories)}

Forrás (Source): Saját szerkesztés (Authors'own compilation)

Megjegyzés (Notes): $\mathrm{N}=191$

\section{KÖVETKEZTETÉSEK ÉS JAVASLATOK - CONCLUSIONS AND PROPOSALS}

A kutatás célja a szabadidős sporttevékenységet végzők étrendkiegészítő fogyasztásának vizsgálata volt. Az eredmények több elemében megerősítik SZỨCS és SZAKÁLY 2020-ban közölt hasonló célú kutatási eredményeit. A kutatás során megkérdezett amatőr sportolók többsége a potenciálisan stabil étrendkiegészítóket fogyasztók közé sorolható. Mindöszsze 10\%-uk nem fogyaszt és nem is tervezi az étrend-kiegészítők használatát. A vizsgált korcsoportban kiemelkedően magas (95\%) arányú a vitaminpótlás, illetve a résztvevók 60\%-ánál megjelenik az aminosav/fehérjepótlás. A vitaminkészítmények napi vagy napi többszöri használata közel 80\%-uknál jelenik meg, míg az aminosavak, fehérjék és az esszenciális zsírok napi vagy napi többszöri szedése is jellemző a válaszadóink negyedére. A kapott eredmények alapján megállapítottuk, hogy a szakirodalmi forrásokban említett arányoknál (CHAPPELL, 2019) magasabb étrend-kiegészítő fogyasztás főként a vitaminkészítmények fogyasztásában mutatkozik meg. HARTMANN és SIEGRIST (2016) eredményeit, amely szerint a proteinfogyasztás kimagasló arányban jelenik meg az étrendkiegészítő fogyasztáson belül nem tudtuk megerősíteni.

$\mathrm{Az}$ étrend-kiegészítók fogyasztási motivációja és mintázata összefügg a végzett sport típusával. Míg az egészségmegôrzés minden sportkategóriában első helyen jelenik meg, az izomtömeg növelése inkább az erőnléti sportolókhoz kötődik, a porcok védelme pedig az aerob eszközmentes sportokat gyakorlók kiemelkedő motiváló tényezője. A szabadidős sportolók körében végzett, sportkategóriákhoz köthető étrendkiegészítő-fogyasztási mintázatok kutatási területén belül csupán néhány kutatási eredmény érhető el a nemzetközi szakirodalomban, azért kutatásunk eredményei újszerünek mondhatók. A fizikai közérzet javítása a második legerősebb driver minden sportkategória sportolóinál. Eredményeink arra utalnak, hogy az étrend-kiegészítók alkalmazásának elsődleges hajtóereje az egészség megőrzése, ugyanakkor szakirodalmi források szerint ezek túlzott bevitele akár az egészség károsodásához is vezethet. Eredményeink alapján jól látszanak az étrend-kiegészítők fogyasztásának korcsoportonkénti motivációs eltérései is. $\mathrm{Az}$ egészségmegőrzés minden korcsoportban első helyen szerepel, míg az izomtömeg növelése és 
teljesítményfokozás a fiatalabb korcsoportok, a porcok védelem és a fizikai közérzet javítása az idősebbeknél mutat magasabb értékeket.

Az eltérő motivációk megjelenése alapján az egyes életkori és sportfogyasztási szegmensek számára differenciált kommunikációs fókusz kijelölése indokolt. Mindemellett a szabadidős sportolók termékismereteinek felmérése további kutatási irányként jelenhet meg.

\section{KöSZÖNETNYILVÁNÍTÁS -}

\section{ACKNOWLEDGEMENTS}

Köszönet az EFOP-3.6.1-16-2016-00015 projekt anyagi támogatásáért.

\section{IRODALOMJEGYZÉK - REFERENCES}

Ács P. (szerk.): Változások a magyar lakosság élet- és munkakörülményeiben kiemelten a fizikai aktivitás és a sportfogyasztási szokások vonatkozásában. 2020. https://www.etk.pte.hu/public/ upload/files/efop362/acspongraccovid19kutatasijelentes.pdf. (Letöltés dátuma: 2021.11.07.)

Beitz, R. - Mensink, G. - Henschel, Y. - Fischer, B. - Erbersdobler, H.: Dietary Behaviour of German Adults Differing in Levels of Sport Activity. Public Health Nutrition. 2004. 7 (1) 45-52. DOI: https://doi.org/10.1079/PHN2003509

Bonjour, J. P.: The Dietary Protein, IGF-I, Skeletal Health Axis. Hormone Molecular Biology and Clinical Investigation. 2016. 28 (1) 39-53. DOI: https://doi. org/10.1515/hmbci-2016-0oo3, indexed in Pubmed:26985688.

Chappell, A. J. - Simper, T. - Helms, E.: Nutritional Strategies of British Professional and Amateur Natural Bodybuilders During Competition Preparation. Journal of the International Society of Sports Nutrition. 2019. 16 (1) 1-12. DOI: https://doi.org/10.1186/ s12970-019-0302-y
Eurostat: Statistics on Sport Participation. 2014. https://ec.europa.eu/ eurostat/statistics-explained/index. php?title=Statistics_on_sport_ participation\&oldid $=542365 \quad$ (Letöltés dátuma: 2021.11.07.)

Hartmann, C. - Siegrist, M.: Benefit Beliefs About Protein Supplements: A Comparative Study of Users And NonUsers. Appetite. 2016. 103 (1) 229235. DOI: https://doi.org/10.1016/j. appet.2016.04.020.

Çöndü, A. - Şener, O. - Türkoğlu, F. N.: Nutritional Habits' Review of Amateur and Professional Football Players. Turkish Journal of Sport and Exercise. 2019. 21 (2) 316-322. DOI: https://doi.org/10.15314/ tsed.585688

Fenton, T. R. - Premji, S. S. - Al-Wassia, H. - Sauve, R. S.: Higher Versus Lower Protein Intake in Formula-Fed Low Birth Weight Infants. Cochrane Database of Systematic Reviews. 2020. 14 (6) DOI: https://doi.org/10.1002/14651858. CDoo3959.pub2

Froiland, K. - Koszewski, W. - Hingst, J. - Kopecky, L.: Nutritional Supplement Use Among College Athletes and Their Soruces of Information. International Journal of Sport Nutrition and Exercise Metabolism. 2004. 14 (1) 104-120. DOI: https://doi.org/10.1123/ijsnem.14.1.104

Hackett, D. - Johnson, N - Chow, C.: Training Practices and Ergogenic Aids Used By Male Bodybuilders. The Journal of Strength \& Conditioning Research. 2012. 27 (6) 1609-1617. DOI: https://doi. org/10.1519/JSC.obo13e318271272a

Housman, J. M.: Understanding Female Collegiate Athletes' Intentions to Consume Sports Supplements: An Application of the Theory of Planned Behavior. Doctoral dissertation. Texas A\&M University, 2003.

Huybrechts, I. - Maes, L. - Vereecken, C. - De Keyzer, W. - De Bacquer, D. - De Backer, G. - De Henauw, S.: High Dietary Supplement Intakes Among Flemish Preschoolers. Appetite. 2010. 54 (2) 340-345. DOI: https://doi. org/10.1016/j.appet.2009.12.012 
Karpik, A. - Machniak, M. Chwałczynska, A.: Evaluation of Protein Content in the Diet of Amateur Male Bodybuilder. American Journal of Men's Health. 2020. 14 (6) DOI: https:// doi.org/10.1177/1557988320970267

Kinczel, A. - Czeglédi, H. - Szabó, K. - Molnár, A. - Bernáth, A. G.: Szabadidősport jelenléte a mai emberek életében. Trendek a versenysport és a szabadidősport területéról. Debreceni Egyetem, Sporttudományi Koordinációs Intézet Debrecen, 2020. 66-78.

King, K. M.: A Qualitative Analysis of Amateur Bodybuilders' Perceptions of Supplements. Middle Tennessee State University. Doctoral Dissertation. 2014

Kiss, A. - Oláh, J. - Popp, J. - Lakner, Z.: Towards Understanding Dietary Supplement Use Among Recreational Athletes on the Basis of a Complex, Multifactorial Model. Journal of Food \& Nutrition Research. 2020. 59 (2) 127-136.

Lehota, J. - Németh, N. - Gyenge, B.: Fogyasztói szokások felmérése az étrend-kiegészítők körében az élelmiszerbiztonság szempontjából - demokutatás. Gazdálkodás: Scientific Journal on Agricultural Economics. 2015. 59 (6) 527-546. DOI: https://doi.org/10.22004/ ag.econ.253791

Lentine, K. - Wrone, E. M.: New Insights Into Protein Intake and Progression of Renal Disease. Current Opinion in Nephrology and Hypertension. 2004. 13 (3) 333-336. DOI: https://doi. org/10.1097/00041552-20040500000011

Linn, T. - Santosa, B. - Grönemeyer, D. - Aygen, S. - Scholz, N. - Busch, M. - Bretzel, R. G.: Effect of LongTerm Dietary Protein Intake on Glucose Metabolism in Humans. Diabetologia. 2000. 43 1257-1265. DOI: https://doi. org/10.1007/s001250051521
Locquet, M. - Beaudart, C. - Larbuisson, R. - Leclercq, V. - Buckinx, F. - Kaux, J. F. - Bruyère, O.: SelfAdministration of Medicines and Dietary Supplements Among Female Amateur Runners: A Cross-Sectional Analysis. Advances in Therapy. 2016. 33 (12) 22572268. DOI: https://doi.org/10.1007/ S12325-016-0426-2

Mangano, K. M. - Sahni, S. - Kiel, D. P. - Kiel, D. P. - Tucker, K. L. Dufour, A. B. - Hannan, M. T.: Bone Mineral Density and Protein-Derived Food Clusters from the Framingham Offspring Study. Journal of the Academy of Nutrition and Dietetics. 2015. 115 (10) 16051613. DOI: https://doi.org/10.1016/j. jand.2015.04.001

Markos, A. - Kiss, V.Á.: Az egészségtudatos életmód tényezőinek vizsgálata az amatőr férfisportolók körében. Táplálkozásmarketing. 2019. 6 (2) 6170. DOI: https://doi.org/10.20494/ $\mathrm{TM} / 6 / 2 / 6$

Mason, G.: Looking Into Masculinity: Sport, Media and the Construction of the Male Body Beautiful. Social Alternatives. 1992. 11 (1) 27-32.

Meer, M. - Misner, S. - Meer, R.: Labeling of Dietary Supplements. Journal of Nutraceuticals, Functional \& Medical Foods. 2005. 4 (3-4) 29-44. DOI: https:// doi.org/10.1300/J133vo4no3_03

OGYÉI: Étrend-kiegészítők. https://ogyei. gov.hu/etrend_kiegeszitok, 2019. Letöltés dátuma: 2021.11.08.

Pajor, E. M. - Eggers, S. M. - Curfs, K. C. J. - Oenema, A. - De Vries, H.: Why Do Dutch People Use Dietary Supplements? Exploring the Role of SocioCognitive and Psychosocial Determinants. Appetite. 2017. 114 161-168. https://doi. org/10.1016/j.appet.2017.03.036 
Pipe, A. - Ayotte, C.: Nutritional Supplements and Doping. Clinical Journal of Sport Medicine. 2002. 12 (4) 245-249. DOI: https://doi.org/10.1097/00042752200207000-00008

Sánchez-Oliver, A. J. - Mata Ordóñez, F. - Domínguez, R. - López Samanés, Á.: Use of Nutritional Supplements in Amateur Tennis Players. Journal of Physical Education and Sport. 2018. 18 (2) 775-780. DOI: https://doi.org/10.7752/ jpes.2018.02114

Sánchez-Oliver, A. J. - Domínguez, R. - López-Tapia, P. - Tobal, F. M. Jodra, P. - Montoya, J. J. - GuerraHernández, E. J. - Ramos-Álvarez, J. J.: A Survey on Dietary Supplement Consumption in Amateur and Professional Rugby Players. Foods. 2021. 10 (1) 7 DOI: https://doi.org/10.3390/foods10010007

Sparks, I. M. - van Rensburg, D. J. Fletcher, L. - van Rensburg, A. J.: A Cross-Sectional Study of 2550 Amateur Cyclists Shows Lack of Knowledge Regarding Relevant Sports Nutrition Guidelines. South African Journal of Sports Medicine. 2018. 30 (1)

Szabó, K. - Kinczel, A. - Czegledi, H. Molnár, A. - Bernáth, A. G.: Fitnesz trendek hatása a fizikai aktivitására, sportolási szokásokra és az életmódelemek változására. Trendek a versenysport és a szabadidősport területéről. Debreceni Egyetem, Sporttudományi Koordinációs Intézet Debrecen, 2020. 149-165.
Store Insider: Az étrend-kiegészítők piaca se makulátlan. 2020.04.03. http:// storeinsider.hu/gazdasag/cikk/az_ etrend_kiegeszitok_piaca_se_makulatlan (Letöltés dátuma: 2021.11.10.)

Swistob, J. L.: Protein Supplementation; A Cross-Sectional Survey of the Perceived Benefits Among Amateur Sports People in Relation to Their Exercise Behavior. Undergraduate Degree (Health Sciences) 2018

Szúcs, R. S. - Szakály, Z.: Fogyasztói tudatosság az étrend-kiegészítők piacán. Jelenkori Társadalmi és Gazdasági Folyamatok. 2020. 15 (3-4) 107-116. DOI: https://doi.org/10.14232/jtgf.2020.34.107-116

Tisza, A.: Étrend-kiegészítők: erősödik az egészségtudatosság. Trade magazin. https://trademagazin.hu/ hu/etrend-kiegeszitok-erosodik-azegeszsegtudatossag/ 2019.05.22. (Letöltés dátuma: 2021.11.10.)

Wirnitzer, K. - Motevalli, M. - Tanous, D. R. - Gregori, M. - Wirnitzer, G. Leitzmann, C. - Hill, L. - Rosemann, T. - Knechtle, B.: Supplement Intake in Recreational Vegan, Vegetarian, and Omnivorous Endurance Runners Results from the NURMI Study (Step 2). Nutrients. 2021. 13 2741. DOI: https://doi. org/10.3390/ nu13082741

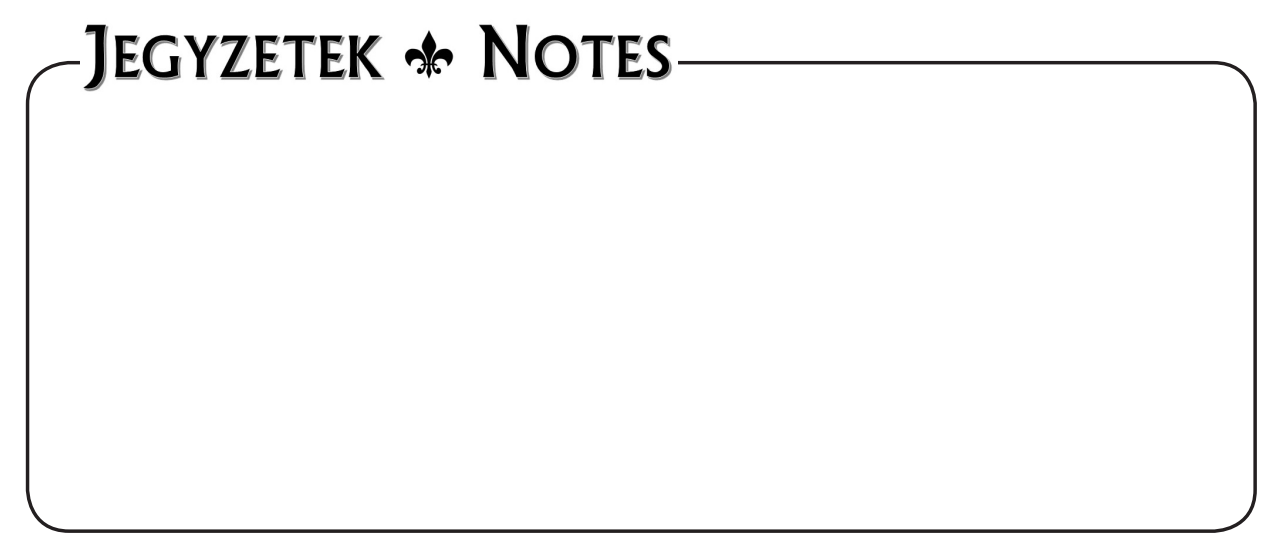

